\title{
LATENCY, LIGHT, AND VOID: KEY CONCEPTS IN CONTEMPORARY ISLAMIC ART
}

\author{
SONDOS BASLOUH \\ Art and Design Department, Jeddah University, Saudi Arabia
}

\begin{abstract}
Islamic art expresses both visual and conceptual elements. It is based on philosophical ideas stemming from traditional Islamic philosophy and religious thought. This study investigates these ideas and exemplifies them further as visual and material concepts. Since the 19th century, Islamic art has been approached and studied from different angles without deeper investigation of its philosophical meanings. In fact, it was primarily explored through its historical context or examined in terms of its material and decorative qualities. This led to a very generalized understanding of traditional Islamic art and affected the creation of new contemporary Islamic artworks. As a result, contemporary artists have distinguished two separate approaches when working with Islamic art. They either use its established visual elements, like Shirazeh Houshiary, or express its conceptual foregrounding, like Idris Khan. I am proposing that both components should be included within the production of new works of contemporary Islamic art. I suggest that by the detailed examination of the conceptual ideas prevalent in Islamic philosophy, which greatly influenced the visual manifestation of Islamic art from the 10th to the 14th centuries, we shall be able to deconstruct and understand the embedded meaning in Islamic art and use these concepts to create new forms of Islamic art. I investigate and contextualize in this article philosophical concepts that I believe have influenced Islamic art over the centuries and resonate considerably in the construct of contemporary Islamic art. These concepts were for the most part used during the formative period of Islamic art and were discussed by different schools of philosophy. The three concepts examined are the concept of light, which reflects nur or illumination; the concept of space, which reflects void; and the concept of geometry, which reflects latency.
\end{abstract}

Keywords: Islamic art, contemporary, nur, light, latency, void, geometry, infinity, philosophy, manifestation.

\section{INTRODUCTION}

Traditional Islamic art was highly influenced by Islamic philosophy and in order to understand its formation we need to investigate the philosophy that was influential at that time. This study investigates conceptual ideas within Islamic philosophy and uses these concepts to create new forms of contemporary Islamic artwork which best reflect them. I then convey my own investigation in one of these concepts through my own practice and through examples of contemporary artists.

The main focus of this study is to exemplify these philosophical concepts from tenth to 14th-century Islamic philosophy and connect them with the range of contemporary art practiced in the Islamic world today. I shall argue that these philosophical issues, among others, influenced Islamic art in the past and gave it its complexity and rich quality. My contention is that in order to formulate and produce new forms of Islamic, they need to reflect some of the philosophical concepts of Islamic art from the past.

With the reinvigorated interest in its art stemming from the MENA region, there are many new contemporary art galleries, such as The Third Line, Gallery Isabelle van den Eynde, Lawrie Shabibi and Green Art Gallery in Dubai and the UAE, museums such as the Jameel Arts Centre at Jaddaf Waterfront in Dubai, the Museum of Islamic art in Doha, competitions such as the Jameel Prize at the Victoria and Albert Museum in London and conferences such as the 2015 Contemporary Islamic Art Design and Architecture (CIADA) conference in Singapore and the 2016 and 2018 WIT Islamic Heritage Architecture and Art conference, 
which all have an impact on art today. All this is a response to the sustained interest from artists in their own heritage and also an increased interest from the West, but the question which still remains is "how can we define contemporary Islamic art?" What makes this work contemporary Islamic and not just contemporary or Western? This recent attention from galleries and museums worldwide is impacting the proliferation of contemporary art from the region and makes it even more crucial and urgent to define it. I shall argue that new forms of Islamic art have to follow the same values and reflect the same concepts as Islamic art from the 14th century. Furthermore, Islamic art cannot be radical or provocative using elements which are prohibited in the religion (the use of nudity, sexual images and insulting the prophets or the Qur'an), otherwise the artwork is considered as "contemporary art" and not "contemporary Islamic art". Many works of contemporary Islamic art are political, cultural or even personal, with some visual elements borrowed from Islamic art. The dilemma that artists have today is mainly caused by the lack of appropriate studies in the field, which requires deeper understanding. I shall suggest that drawing upon conceptual ideas from Islamic philosophy which influenced Islamic art from the tenth to the fourteenth centuries could help us to understand the deeper meaning behind Islamic art and use these founding concepts to create new forms of Islamic art which better reflect the religion and the ideology within it.

In a time when contemporary Islamic art is becoming more and more relevant and accepted in the globalized art world, my research examines how these philosophical concepts can reflect these ideas both visually and conceptually. The research process allows me to contextualize a philosophical framework for artists today with the aim of creating new forms and expanding the understanding of Islamic art in a way that better reflects its conceptual and philosophical history. This proposed framework could assist artists that are interested in creating contemporary Islamic artworks.

In this article, I will present three philosophical concepts which have influenced Islamic art. These concepts were popular issues during the formation of Islamic art in the 13th century and were discussed by different schools of philosophy. I will explore these notions not only philosophically but also visually in my own practice.

The three philosophical concepts are:

1. The concept of Light which reflects Nur or Illumination, which is the mystic concept of God's light and our relation to Him; and

2. The concept of Space which reflects Void, which is the philosophy of the invisible and the non-existent;

3. The concept of Geometry which reflects Latency, which is the hidden aspect of Islamic art.

Across this geographical spread and long history, Islamic art went through several periods of development which led to different styles and changes. Despite these differences, they all maintained an essential quality and unique identity. This essential quality is what makes Islamic art recognizable as a unified type of art. Islamic art shares similar style of creating interlocking geometrically shaped motifs from floral and vegetal forms in addition to other qualities of balance and symmetry. The aspect of Islamic art that I use in this current study is focused on these similarities which are shared by most forms of Islamic art and this enables me to investigate the fundamental elements which it expresses. 


\subsection{The philosophy within the art}

Science, thought and spirituality in Islamic culture form an interwoven practice. Philosophy played an important role in providing logic and rational tools for the development of these practices. In fact, the difficulty in categorizing many Islamic thinkers in a particular speciality as scientists, theologians, philosophers or mystics confirms the interwoven field of knowledge in which intellectual activity blended the sacred with the secular. Consequently, the development of knowledge has been reflected in the quality of the arts. Indeed, it is no surprise that Nasr claimed in Islamic Art and Spirituality that "It is not accidental that whenever and wherever Islamic art has experienced a peak of its creativity and perfection there has been present the powerful, living intellectual - which also means spiritual - current of the Islamic tradition. And conversely, this causal nexus provides the reason for understanding why whenever there has been a decay or eclipse of the spiritual dimension of Islam the quality of Islamic art has diminished" [1]. So whenever Islamic art was at its highest form of creativity and perfection, a power of intellectual activity as well as spirituality can be found and, whenever there is low intellectual activity in the area, the arts will be less developed. There appears to be a strong connection between knowledge and philosophy and the arts.

Throughout the Islamic civilization, Muslims have developed a different way of viewing the world [2]. This provided them with a specific artistic expression. Scholars have argued that Muslims during the period from the eleventh to the fourteenth centuries built a symbolic language in art and literature. Some support this assumption, such as Hamdouni Alami [3], with evidence from the transformation of language in poetry before and after Islam, where a more symbolic expression was developed. Others such as Tabbaa [2] have stated that forms of symbolism in the visual arts were encouraged by rulers during the late Abbasid caliphate and were accepted and later developed by the rest of the Islamic world.

The development of a symbolic language was also a very important element in theological and philosophical writings. The 11th-century text of Abu Hamid al-Gazzali's Mishkat al-Anwar ("The Niche of Light") contains descriptions of God's light; al-Gazzali established visual theories which offered a view of the phenomenological world in relation to God [4]. Suhrawardi, an 11th-century Shaik al-Ishrag luminous philosopher, also wrote similar ideas about perceiving light through the physical eye and what a human being can envision [1]. Hence the relation between the physical and the spiritual discourses overlaps and is expressed in a symbolic language in the writings of many Islamic thinkers.

\subsection{Contemporary artists exploring the concepts}

Over the years from the 1960s, contemporary art pioneers across the world have been using concepts in their work. Whether the source of the concepts is from Islamic philosophy or other philosophies, these artists all share conceptual qualities even though their approaches are unique and very varied. Conceptual and Minimalist artists such Sol LeWitt, Frank Stella and Mark Rothko explored the notions of latency and geometry in their work and they reduced the object and minimized the form (Fig. 1). Geometric repetition is one of the main visual elements used in their works. The prolific installation artist Olafur Eliasson frequently plays with the concept of light and infinity in different ways. James Turrell also works with the concept of light and space. His art practice depends on manipulating the viewer's experience. These are only a few of many contemporary artists who have explored concepts which enhance the viewers' experience by encouraging them to look beyond what they see. An occurrence is also found when comprehending the parameters of Islamic art. In fact, Laura 
Marks suggested that Islamic art influenced modern Western art when she stated that "Undoubtedly the many techniques of abstraction, algorithmic construction, tactile surface qualities, meditative repetition and other qualities found in various Islamic arts influenced the rise of Western modernism" [5].

London-based conceptual artist and writer Rasheed Araeen has commented that Minimalism shares fundamental elements with Islamic geometry, such as symmetry and seriality. He explained that in order for contemporary Islamic artists to move forward into the modern world as an art movement, they need to find elements from traditional Islamic geometry and use them in their work [6]. The parallel between these two art forms makes this current study even more relevant to the field today.

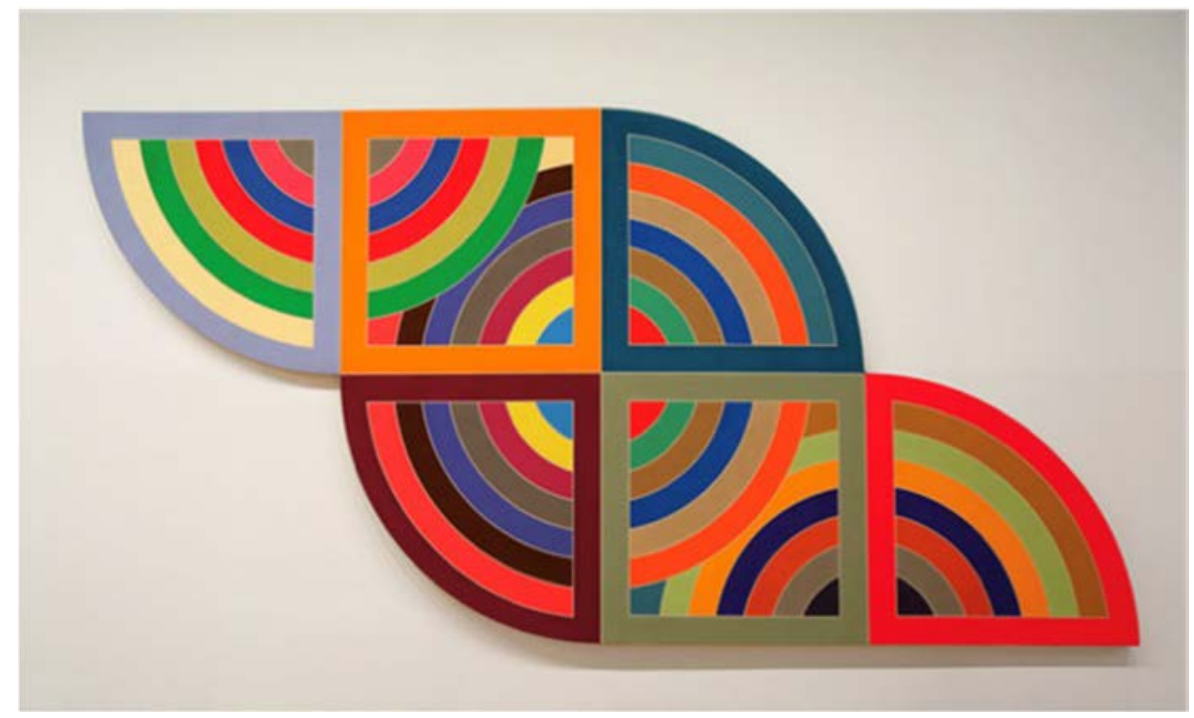

Figure 1: Frank Stella, Harran II, 1967.

\section{THE CONCEPT OF LIGHT WHICH REFLECT NUR OR ILLUMINATION}

Light is an important component and a connecting theme in Islamic art, both physically and metaphysically. Nur is the Arabic word for light. In Islam, light is one of God's attributes, therefore $\mathrm{He}$ is the source of all light and goodness in the world. It is believed that light is behind all creations, both physical and spiritual. In Islamic philosophy, light is presented through the school of Ishraqi illumination founded by the Sufi Shaykh al-Ishraq Shihab al-Din Suhrawardi. He considered light to be the very substance of reality. Nasr explained the illumination philosophy which is based on the metaphysics of light as "the origin and source of all things is the Light of lights (Nur al-anwar), which is infinite and absolute Light above and beyond all the rays that it emanates. All levels of reality, however, are also degrees and levels of light distinguished from each other by their degree of intensity and weakness and by nothing other than light. There is, in fact, nothing in the whole universe but light" [7]. Light projects a transcendent unity. The Qur'an is considered as one of the literal places which contain God's light since it is the only miracle of Islam which contains the sacred words of God. The concepts light, reality and the absolute being are bound together by a single philosophy to illustrate the vastness and all the inclusivity of light as an idea and reality both conceptually and literally. 
Since the Qur'an is considered to consist of God's words and God is considered as "Light upon Light," the Qur'an contains God's Light. Artist and calligraphers took special interest in these manuscripts for their sacredness. Ninth-century manuscripts of the Qur'an were written with golden ink, which was exclusively invented in a practice named illumination by an illuminator who worked closely with the calligrapher [8]. This golden text is regarded as illuminated text (Fig. 2). Illumination was also explored in ceramics when lusterware was developed as a technique. It was first invented in the 8th century in Iraq then was adopted and later used by other Islamic ceramicists across the Islamic world, such as Syria.

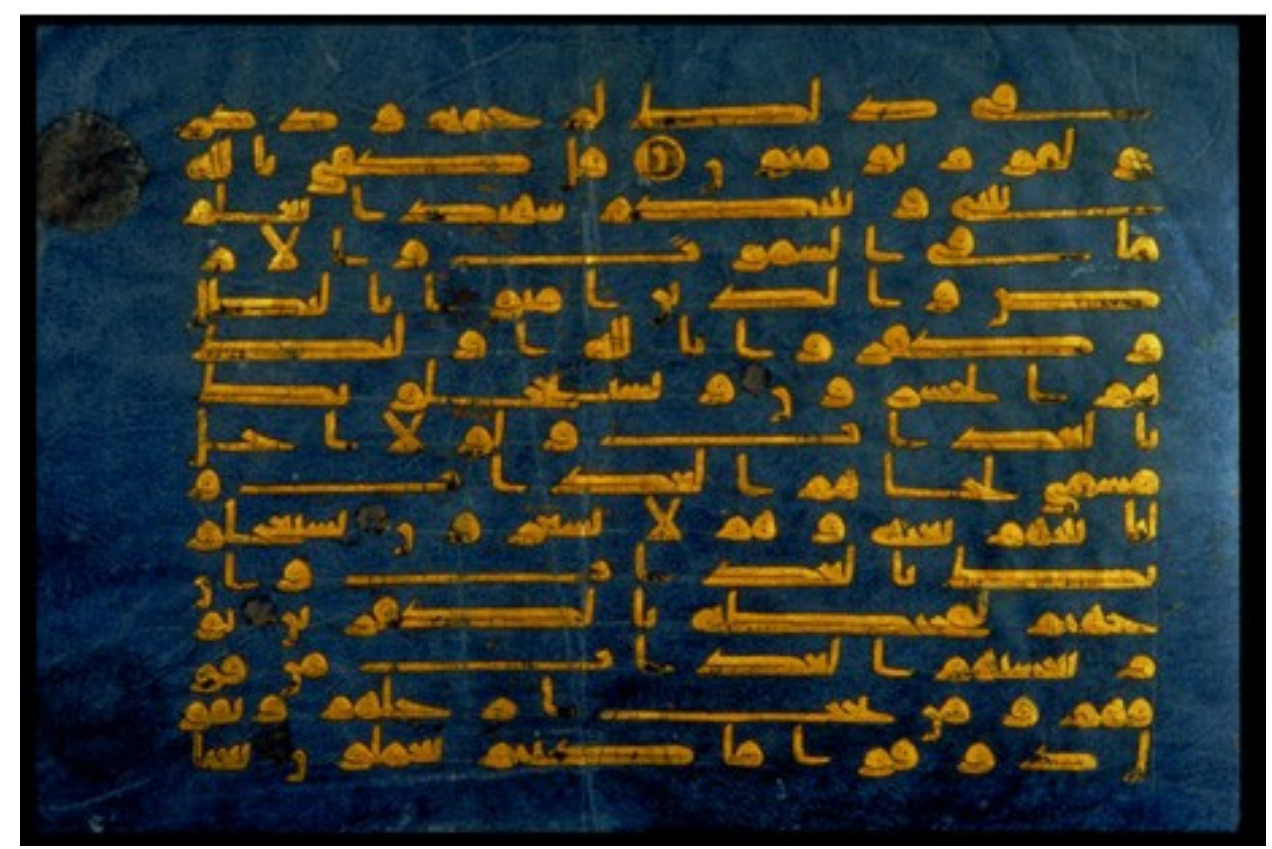

Figure 2: $\quad$ Page from the Quran in Kufic script, Probably Kairouan (Tunisia), late 9th-early 10 th century.

Illumination techniques are still used today without much change in their process and applications. Many traditional Islamic artists today are using the same methods of gilding from the 13th century. In Istanbul, there are schools which teach Islamic illumination in manuscripts (tazhib) to gain a specific qualification called ijaza, which means permission for the artists to pass on their apprenticeship in tazhib to future generations with the same quality and teaching. Contemporary artists have been using the concept of light in different ways. For an example, Iranian-British artist Shirazeh Houshiary and the Moroccan-French artist Mounir Fatmi. In a number of their work, both artists are clearly inspired by the concept of light in Islamic philosophy; they have explored a number of its key elements by formulating their work in response to concerns and questions about our existence. For instance, Houshiary explores the Sufi path of illuminating the heart from darkness to light in Licit Shadow (1993). On the other hand Fatmi installation In the Absence of Evidence to the Contrary (2012), which he used fluorescent lights to form the structure. On the fluorescent lights are printed verses from the Qur'an (Surah al-Nur 24) in both Arabic and English. These verses explain 
God's light which exists in the heavens and on earth. The concept of nur or illumination in Islamic philosophy is based on the theory of the essence of our existence. In that respect the source of all existence is from God's light and without it there is no existence. Contemplating the emanation of God's light in His creations can suggest a spiritual journey which starts from within.

\section{THE CONCEPT OF SPACE WHICH REFLECT VOID}

The concept of void is a notion that can be grasped in one of the theories which are central to Islamic philosophers, the wahdat al-wujud, "The unity of God". This theory derives from the shahada, the basic belief of a Muslim, which not only means that there is no God but God, but also that there is no existence except God's existence. God is the ultimate reality of being, the first and the one. Everything else in the universe is manifestations of God and is at the same time distinct from existence. Al-Gazzali and the Mu'tazila believed that all realities are subdivided into existences and non-existences. To Sufism, all existences are unreal because they are not derived from God's reality. The realities are complete manifestations of the perfect Being, which creates a unity between God and his creations. The emanation of God into His creations does not make them part of God but in relation to God's existence, "in essence" all creations in reality are ma'dum, non-existent or void. Ibn Arabi wrote that "Although we are existents, our existences are through Him; and everything whose existence is through something else equals nothingness" [9]. Metaphysically, all existences have presence. One of the Sufi understandings of the reality of the world and its metaphysics is through presence, hudur, and absence, ghiyab. Akkach stated that "Every existent has a presence that matches its mode of being. Even non-existence has a notional presence" [10]. So presence is a combination of all the physical, mental and spiritual existences and their ability to affect and impact on each other, whereas absence is the lack of this performance regardless of its physical existence.

In Islamic art, we can find there are two approaches to the concept of the void which are addressed in Islamic philosophy. The first is that if God is considered to be the ultimate existing being, then there must be nothingness in the void. This means that God is the only thing which is real in the universe and that everything else is void. The second approach is that if the objects in the universe are considered as existing things, then the void is the emptiness around them, and it can represent the presence of God. In this respect, the void can either symbolize the transcendence of God in the universe or His presence in the universe [1]. The establishment of this philosophy, which is only valuable with God as its principle, should also influence sensibility to the use and order of space in all different fields, including art.

Within Islamic art, we can find both reality and unreality existing in a harmonious whole. As far as Islamic art, it can easily be recognized that the positive forms or shapes and the negative spaces are equally important. There is the same amount of empty space as there are shapes in ornaments, geometry and architecture. Akkach argued that the compositional qualities in most Islamic architecture from different styles and historical periods such as the Taj Mahal, the Sultan Ahmed Mosque and the Dome of the Rock Mosque share the same sense of spatial ordering [10] (Fig. 3). The correlation in the use of spaces in Islamic art connects different styles and periods together. They are all unified in their tendency to geometrically order spaces in a symmetrical manner. In addition, the focus on space in all forms of Islamic art enhances the compositional balance between all the parts of the work. The strong sensibility to space and order comes from the theological understanding of our existence and the non-existent. 


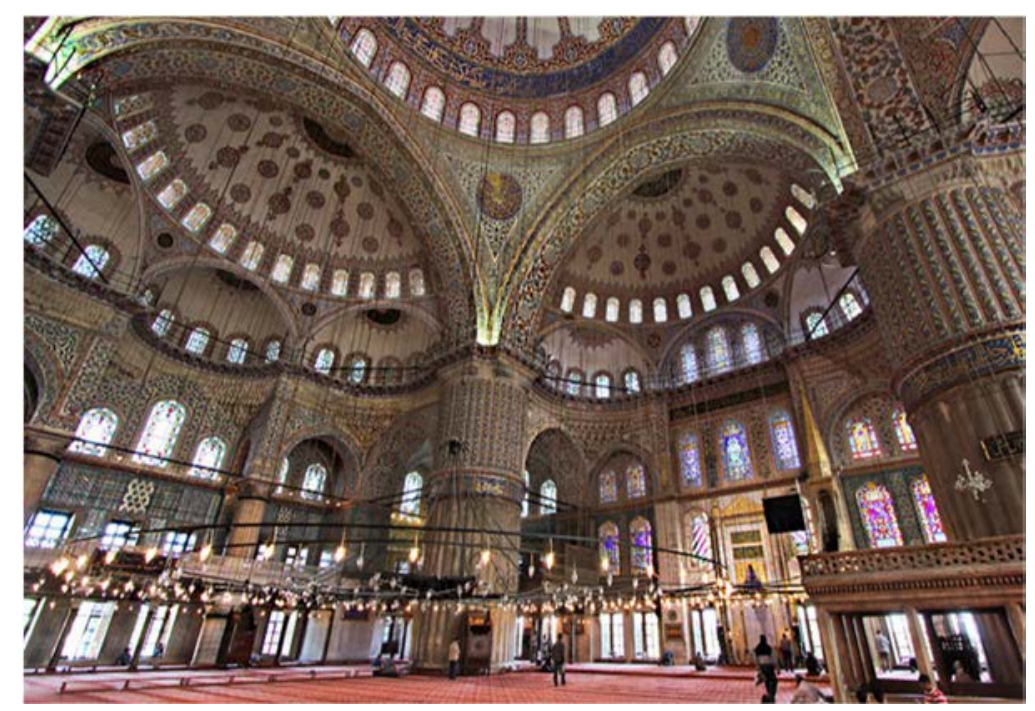

Figure 3: Interior view of Sultan Ahmed Mosque in Istanbul 17th century.

The non-existent things can exist only by the Divine light turning them from the darkness of nothingness into lighted existence. Philips wrote that "Light is indivisible, not altered by its refraction into colours nor diminished by its graduation into clarity and darkness. Similarly, nothingness does not itself exist except by its illusory opposition to being; so also darkness is visible only by contrast with light, to the extent that light makes shadows appear" [11]. So, non-existence is a void which has yet to exist by God's light and His existence. This can be seen as another way to address the void as darkness which will not exist without light. In addition, we can also comprehend how non-existence comes to existence. In this way, the concept of the void overlaps and connects with the concept of light discussed earlier. These binary opposites which validate each other's relevance co-exist to define each other. This also shows how these concepts are interwoven not only in their theories but also in their manifestation in art.

Contemporary artists such as the well-known British artist Anish Kapoor has dedicated a considerable amount of his work to express the void concept. He explored the notion of matter and non-matter, the material and the immaterial, through the concept of void [12]. Whether it is black empty voids or mirrored surfaces, he seeks to visually overwhelm the viewer. His approach manifests notions which lie below the surface of the material, which makes his work always hidden and latent. Contemporary Iranian artist Sahand Hesamiyan also have been exploring the concept of void in his work. In is work, he is particularly interested in the geometry of the Islamic domes and their spiritual metaphysics. His sculptures are usually large-scale and primarily produced from steel. Hesamiyan's intention in his sculptures Memory Lives On (2011) and Sulook (2013) is to have forms which unconsciously remind the viewer of the shapes in Islamic geometric patterns and in the interiors of the Muqarnas domes, moving simple shapes of squares, rectangles and triangles into interwoven compositions. These shapes do not exist in the sculptures but are embedded within the negative and positive spaces. The hollowness of his work as well as through the employment of empty spaces within the work shows that Hesamiyan comprehends well the connection between both the visual and conceptual component in Islamic art. 


\section{THE CONCEPT OF LATENCY THAT REFLECTS GEOMETRY}

In Enfoldment and Infinity An Islamic Genealogy of New Media Art [13], Marks suggested that there are clear parallels between Islamic art and computer art as both of them share an algorithmic structure. Her proposition can be seen as one of the main elements which are essential when creating contemporary artwork with the intention of expressing infinity. This suggests that having a geometric structure is an important way of expressing a visual concept of Islamic art. Most importantly, geometry can be used as the visual element to express the concept of geometry which reflects latency. In Islamic art, latency is expressed through a philosophical issue which was very central to the history of Islamic philosophy, the study of being and its manifestations; the question of the wujud (existence) in itself and its relation to the mahiyyah (essence). Many different schools of Islamic philosophy have investigated the unity of God and His relation to the world's multiplicity. This concern can be traced back to Greek philosophy; the early Islamic philosophers al-Farabi (872-950) and Ibn Sina (980-1037) were the first to discuss it in the Muslim context and later most philosophers contributed to the subject, each having different opinions [7].

The concept of latency is also expressed in the theory about the zahir and the batin, two of God's attributes. Every type of Islam addressed these concepts Al-Zahir and Al-Batin. Sufism, or al-Tasawwuf, defined them as the inward batin aspect of Islam featured from an external zahir [14]. The Sufi path, which opens the soul to spirituality, leads to experiencing the infinity of the Divine. Zahir and batin are used to explain God's manifestation in the universe. The realities are the visible zahir manifestation of God who is latent batin within them. They believe that all beings are God if we think of their essence, but God is not those beings for $\mathrm{He}$ is beyond comprehension and His existence is latent.

The existence of God in his creations seems to be hidden and latent in the universe. We can read or unfold this latency of God by contemplation, which should eventually lead to understanding the infinity of God. In Islamic art from the 11th century onwards, the latent interface of God is reflected through infinitely complicated geometrics, repeated patterns and an exactness of proportions. Its avoidance of figurative representation eases the viewer into a contemplative state. The perceptible image in Islamic art can be read through the imperceptible and subliminal elements which it expresses.

Geometry is a commonly used visual method to express infinity in Islamic art whether it is ornamentation, calligraphy or architectural filling. Most visual aspects of Islamic art are based on geometrical structure. All this geometry, with its repetition, symmetry and reflection, illustrates a visual sense of extended infinity. Geometry here facilitates the movement of sight and thought to unravel the underlying concept of infinity. Khemir wrote that the "geometric pattern alludes to the intrinsic cosmological laws governing all creation and attests to the essential unity of all things" [8]. It is geometry that plays the role of guidance to the mind from the physical world to the underlying reality and the latency of God. There is a strong connection between latency and geometry: latency can only be unfolded through geometry. Therefore, infinite geometry leads to latency.

\subsection{Contemporary artists exploring the concept of latency}

Many contemporary artists use similar concepts in their work. For an example Moroccan artist Younis Rahmoun and British artist Idris Khan both drew upon the concept of latency in their work. Each artist's inspiration and application are different from the other. In Rahmoun's work, he always seeks to bridge between the visible and the invisible. He developed various elements and started to incorporate them in his work. Elements such as space, numbers, repetition, orientation towards Mecca, the colour green and light have all 
been explored by him. These elements were developed through a personal spiritual quest. In his work Habba (2008), which is an animated video of a seed which grows into a tree, Rahmoun tells a story of the seed which travels and searches for the perfect place until it settles and grows its roots, branches and fruit until new seeds come and the cycle begins again. The work was shown in an exhibition entitled Habba-Zatuna during Spring 2015. The title Habba translates as "seed," which is latent, and Zatuna is "olive," the fruit or the manifestation. Monsallier interpreted this work as follows: "This rapprochement between the seed and the fruit is reminiscent of the metaphor of the crust and the core handed down by tradition. The rind symbolizes the surface meaning, the kernel stands for the hidden meaning of an Epiphany accessible only through personal labor (sic) and effort" [15]. Rahmoun's concept of a seed and its growth into a plant offers an expression of latency and its manifestation. This is similar to the Sufi search for truth which comes from within a person's core. Its repetition demonstrates the cycle of life on day-to-day basis and the way that it purifies the heart from bad actions and sins, searching from within our soul and inner being.

Khan used the same method in his Beginning at the End (2013) exhibition in Dubai. To form his stamped-over layered text, he used Arabic scripts inspired by Islamic philosophers such as Ibn Sina, Ibn Rushd and al-Gazzali. The use of the Arabic language adds a Sufi-like mystical quality to the work. In this series, he questions the process of creating art by exploring Islamic philosophies about the creation of the world [16]. He explores the use of philosophical thinking about our existence to understand his artistic practice and how it is performed through a process. This way of contemplating is a Sufi practice, questioning the unity of God's creation and our relation to Him. For Khan, the artist is the creator, the artworks are his creations and the practice of coming to the studio every day is a ritual performative practice. We can therefore say that his artistic practice has a spiritual purpose. The technique of stamping in itself can be also interpreted as a metaphor for the manifestation of God in His creation and His latency in the universe. Stamping can also be as seen as belonging, as a collective, to the Creator of whose identity we are merely mirrors or replicas. As the artist stamps the sentences, they become manifested, but as he layers them on top of each other they become hidden and latent. What is visualized in the end is the abstract effect of his layering; and that is exactly how God is latent or batin.

\subsection{Latency manifested in my practice Mirrors of the Unseen}

In Islamic philosophy, the notion of "mirror" and "reflection" is used to express our existence and its relation to God's existence. Every aspect of God's creation in the universe is a reflection of Him, and His existence is latent and hidden. In the project Mirrors of the Unseen, I thought about ways to reflect the concept of latency and infinity through geometry. It is important to point out here that it is my intension to manifest the conceptual element of latency with the visual element of geometry at the same time.

Mirrors of the unseen is an installation made from eight-millimetre Perspex mirrors in the shape of a prism. On one end there is a transparent acrylic sheet to which small ceramic pieces have been glued in a pattern (Fig. 4). The prism is open on the other end for the viewer to gaze through at the work. Behind the ceramic pieces there are LED lights on a stand illuminating the interior of the installation. The ceramic pieces are reflected infinitely in the mirrors in a pattern (Figs 5 and 6). When gazing through the pattern, the viewers are urged to contemplate. What they see is an abstraction of a deeper dimension. There is more to what they are seeing, a transcendence of a higher reality. The universe, as explained by the 11 thcentury Islamic philosopher Ibn Al-Arabi, is essentially a set of mirrors in which the Divine 
realities are reflected. It is a visible manifestation of God and humankind [17]. This installation is about God's latency and the hidden existence of Him in His creation and His infinite multiplicity in the universe. God is everywhere and there is no limit to His existence. Everything in the world is a reflection of His existence. The forms and their reflections in my installation are latent with God's existence. Through the different sizes and forms of the ceramic pieces, the viewer can experience a sense of unity and interconnection because they all come from a single source. Regardless of the expansion of the forms, they are all generated from the same source, the original and the "one," which is God. The exactness of the proportions of these interlocked shapes shows God's perfection in His creation of the universe. Moreover, the installation's underlying algorithmic structure is latent and hidden and can only be manifested though contemplation and observation. In fact, gazing through these luminous shapes shows how similar they are to the stars in the sky shining through the atmosphere. One needs to gaze through them in order to admire their infinity (Fig. 7). The reflections symbolize the reality of our existence (Fig. 8). Mirror reflections are a way to show the world's many different appearances and also imply the impossibility of knowing the truth about our reality. The reality is latent knowledge only known to God and is manifested in his creations through light.

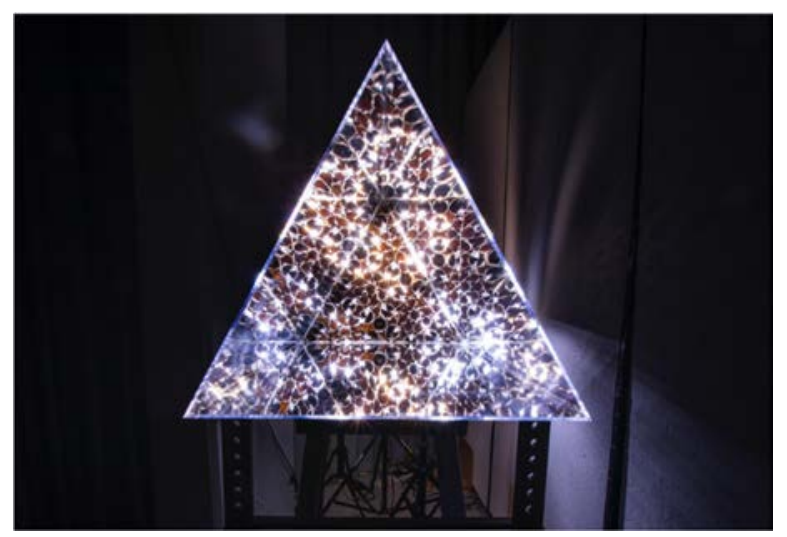

Figure 4: Sondos Baslouh, Mirrors of The Unseen (2019).

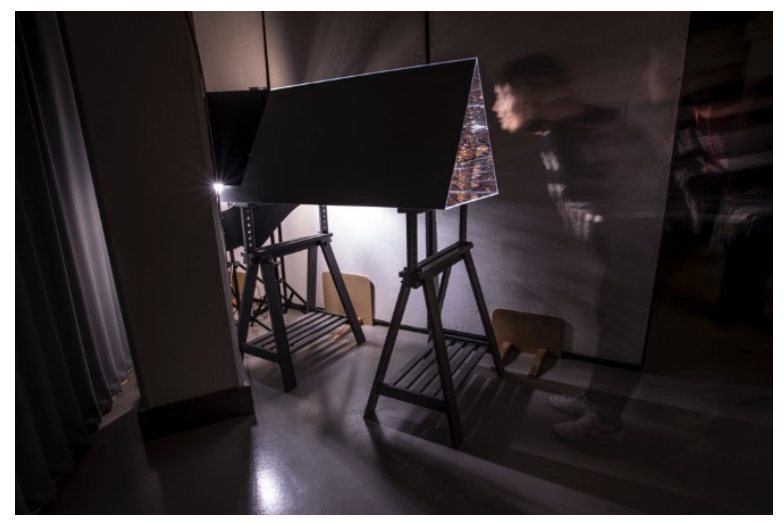

Figure 5: Sondos Baslouh, Mirrors of The Unseen (2019). 


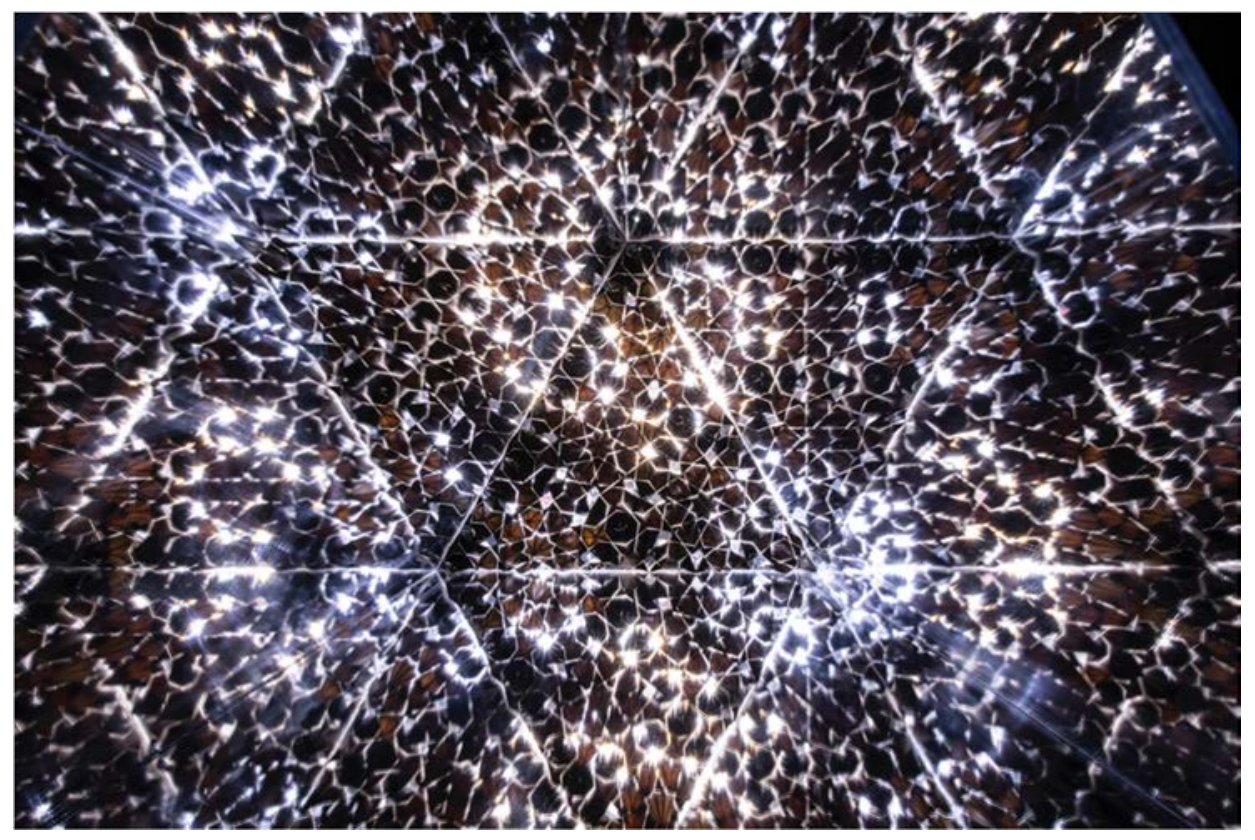

Figure 6: Sondos Baslouh, Mirrors of The Unseen (2019).

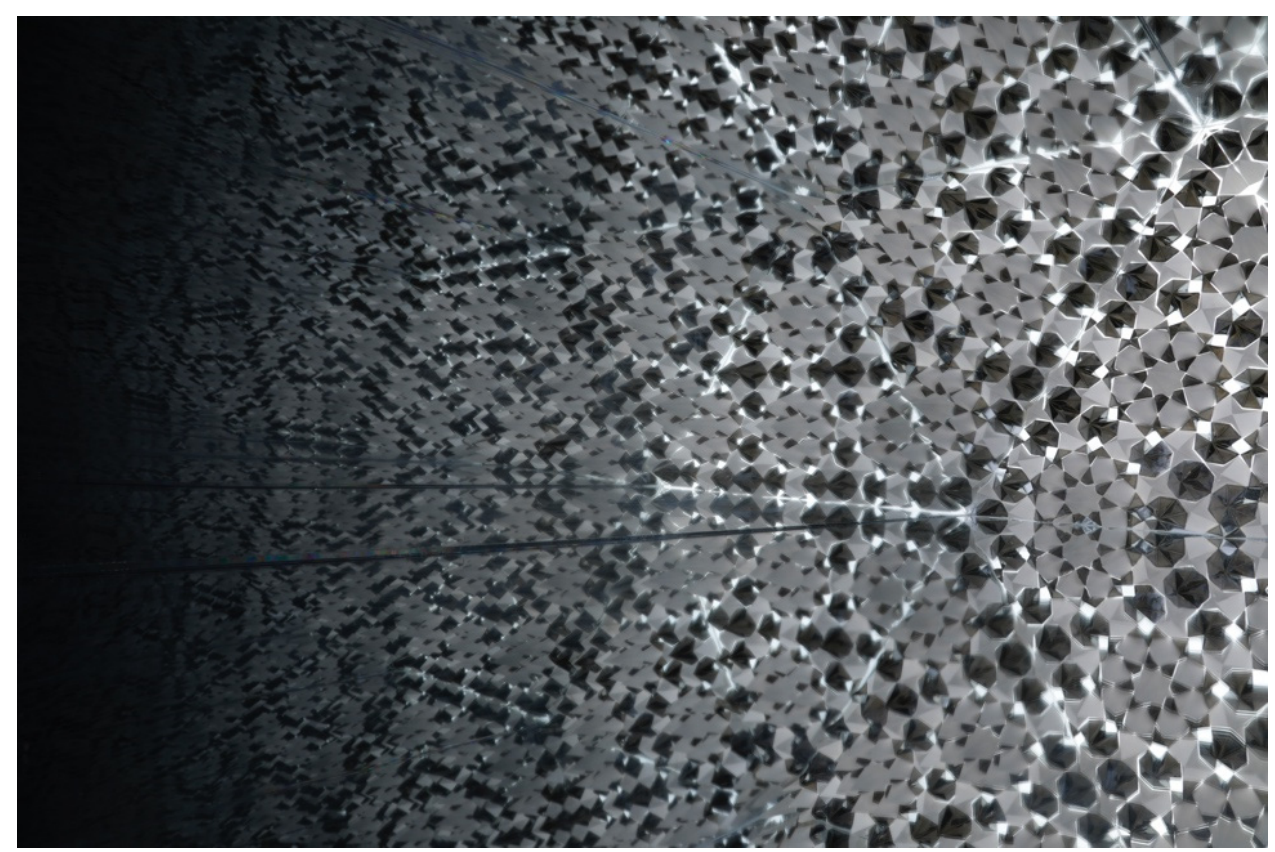

Figure 7: An internal shot of Mirrors of The Unseen (2019). 


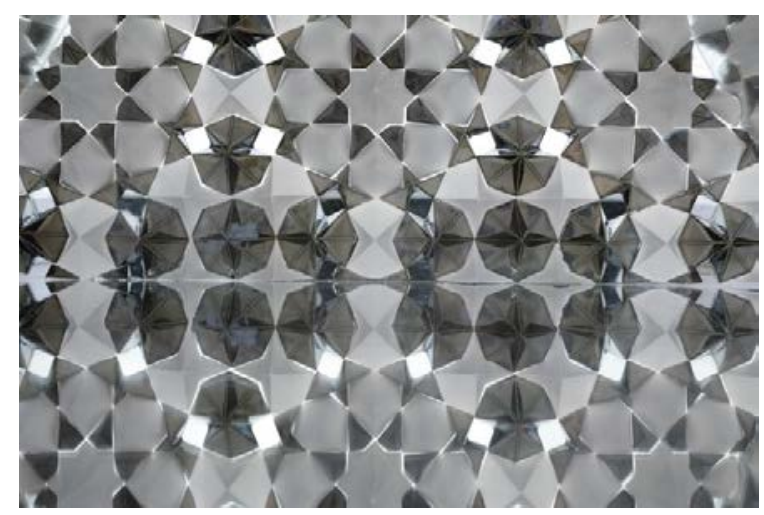

Figure 8: Close up shot showing the reflection in Mirrors of The Unseen (2019).

The true meaning of Islamic art lies in the Islamic intellectual literature adabb, which is a combination of writings on philosophy, poetry and science. Shaw [18] explained the problem with contemporary art historians lack of understanding the potential importance of building a theoretical Islamic module for perception and saw the importance of studying the field by drawing conceptual meanings from Islamic philosophy, where she wrote that this type of historical study "indicates an otherwise unacknowledged need for Islamic art to be conceptualized through an epistemology grounded not simply in formal or even secular/historical terms, but in meanings rooted in Islam itself" [18]. Her argument confirms that Islamic art should be properly conceptualized from a religious Islamic perception. Conceptualizing meanings for Islamic art should be from sources within Islamic text. Unlike other historical arts such as Buddhist art, we cannot find any direct literature linking Islamic art with Islamic philosophy, but we can draw some conclusions about Islamic art and how it was intellectually perceived. It is my intention in this study that the most appropriate way to investigate these theoretical meanings of Islamic art is through investigating different arguments in Islamic philosophy. By investigating concepts and ideas, which were mainly raised in Islamic philosophy and were argued at length by philosophers during that time between the tenth and fourteen centuries, it is possible that this will give us a more suitable direction into understanding the meaning behind Islamic art.

The study of Islamic art has so far been through a variety of approaches like history and archaeology. Research in this field should be investigating it on a deeper level. It has been also misguided to examine it through Western aesthetics instead of focusing on the content of Islamic art through Islamic philosophy. The lack of appropriate studies has caused many problems; Alami (2011) stated that "The near absence of architectural criticism in many Arab and Muslim countries facilitates the largely unquestioned propagation of these views, and has opened the door to superficial speculation about the meaning and identity of art and architecture of the Islamic world" [19]. These approaches have varied from being superficial and often only coincidentally juxtaposed, to being personally vested and often vague and limited in their holistic understanding about a vast body of work. In order to truly understand Islamic art and its inner meanings, it is necessary to study the context and mentality within which it was produced and to highlight its concepts and perceptions. It is also important to understand the way in which these notions and concepts influenced the arts. With this valuable approach to the study, it will only then be possible to find new ways to create Islamic artworks. 


\section{CONCLUSION}

In this study, I have explored concepts from Islamic philosophy in order to find new ways to form contemporary Islamic art. Islamic art is usually introduced through its shared values, such as the abstract nature of the visual elements, their repetitive placement, symmetry and the use of space. The connection of these elements with a theoretical foregrounding is frequently missing. I have presented three conceptual components from Islamic philosophy, which can all be manifested visually, as well as theoretically in works of art. Through my investigations in Islamic philosophy, I have discovered its vastness and popularity. I grasped the strong connection between different sciences and practices in the 13th century and found that among these practices there are also strong references to Islamic art. Islamic art reflected the philosophy which was prevalent at the time. This means that we need to investigate the Islamic philosophy of the period in which Islamic art was formed in order to understand its true meaning.

Through my investigation of Islamic philosophy, I have supported my arguments about the three proposed concepts by highlighting different issues and themes of thought and have connected them through their visual aspects. The connection between the visual elements and their conceptual meaning provides artists with a more evocative way that better reflects the nature of Islamic art. It also enriches the artistic expression in a variety of approaches in a way that is more relevant to the field of contemporary art today. I have attempted to formulate a practical framework for artists to follow when creating contemporary Islamic art. This framework consists of conceptual ideas which can be manifested visually. The works of artists that follow the framework that I have proposed whether it is stemming from Islamic philosophy or not, could still be considered contemporary Islamic art. The key concepts, which I have explored, exemplify how the visual elements in Islamic art can unfold Islamic philosophy. These concepts are only the beginning of what more can be explored within Islamic philosophy. By investigating this wide field and wealth of knowledge, research could find more philosophical thoughts, which can be studied conceptually and applied visually to artistic practices.

In Mirrors of the unseen, it is important to note that although I have based my work on a traditional Islamic pattern, I believe that contemporary Islamic artworks can move beyond the traditional patterns and work in any shape or form as long as it uses concepts which are reflected in Islamic art, as the ones which I have proposed are, visually as well as conceptually. Contemporary Islamic art can consist of two-dimensional paintings, three-dimensional sculptures or installations which occupy spaces, and can be made from any material since they all manifest the concepts of geometry, light and space. New contemporary Islamic works preferably should reflect on these notions, both visually and conceptually. This study opens new discussions around contemporary art in the Middle East and also makes connections with the recent interest stemming from the West. In addition, by bridging art with Islamic philosophy that involves questions about God and our existence can also spur ways of sensing and connecting with one's own belief and practice. Through these proposed concepts, I hope that I have created the beginning of a theoretical bridge between Islamic art in the past and Islamic art in the future; a bridge which can provide a framework for contemporary artists to use in their work to create new forms of Islamic art. Contemporary Islamic art is an art form which is thriving every day and that is something which requires further exploration. 


\section{REFERENCES}

[1] Nasr, S.H., Islamic Art and Spirituality, Golgonooza: Ipswich, 1987.

[2] Tabbaa, Y., The Transformation of Islamic Art During the Sunni Revival, I.B Tauris: London, 2001.

[3] Hamdouni Alami, M., The Origins of Visual Culture in the Islamic World: Aesthetics, Art and Architecture in Early Islam, I.B. Tauris \& Co Ltd: London, 2015.

[4] Shalem, A., What do we mean when we say Islamic Art? An urgent plea for a critical re-writing of the history of the arts of the Islam. Journal of Art Historiography, $\mathbf{6}$, 2012.

[5] Marks, L.U., Infinity and accident: Strategies of enfoldment in Islamic Art and computer art. Leonardo, 39(1), pp. 37-43, 2006.

[6] Araeen, R., Preliminary notes for the understanding of the historical significance of geometry in Arab/Islamic thought, and its suppressed role in the genealogy of world history. Third Text, 24(5), pp. 509-19, 2010.

[7] Nasr, S.H., Islamic Philosophy From its Origin to the Present: Philosophy in the Land of Prophecy, State University of New York Press, Albany, 2006.

[8] Khemir, S., Nur: Light in Art and Science from the Islamic World, Focus-Abengoa Foundation: Seville, 2014.

[9] Kakaie, G., The extroversive unity of existence from Ibn Arabi's and Meister Eckhart's viewpoints. Topoi-an International Review of Philosophy, 26(2), pp. 177-89, 2007.

[10] Akkach, S., The presence of absence: Sacred design now. Design Philosophy Papers, 8(1), pp. 49-55, 2010.

[11] Philips, G., The spirituality of Islamic beauty. Melintas, 28(3), 2012.

[12] Cole, I., Anish Kapoor: Trancending the object. Sculpture Magazine, 29(1), pp. 23$25,2010$.

[13] Marks, L.U., Enfoldment and Infinity: An Islamic Genealogy of New Media Art, The MIT Press: Cambridge, MA, 2010.

[14] Burckhardt, T., An Introduction to Sufi Doctrine, translated by D.M. Matheson. Kazi Publications: Lahore, 1971.

[15] Monsallier, M., Habba - Zatuna Younes Rahmoun, Press Release. Selma Feriani Gallery, 2015.

[16] Kalsi, J., 'Khalvat' reveals hidden layers. Gulfnews 2014. https://gulfnews.com/ culture/arts/khalvat-reveals-hidden-layers-1.1421635. Accessed on: 25 Sep. 2018.

[17] Nasr, S.H., Three Muslim sages: Avicenna, Suhrawardī, Ibn 'Arabī, Caravan Books: Delmar, 1976.

[18] Shaw, W.M.K., The Islam in Islamic art history: Secularism and public discourse. Journal of Art Historiography, 1(6), p. 1, 2012.

[19] Alami, M.H., Art and Architecture in The Islamic Tradition: Aesthetics, Politics and Desire in Early Islam, I.B. Tauris: London and New York, 2011. 